DOI: $10.2478 / \mathrm{sjdv}-2020-0016$

\title{
Autoimplantation - An Immunological Treatment For Multiple Warts
}

\author{
Abhineetha HOSTHOTA, Bindushree REDAPPA', Savita KOREGOL ${ }^{2}$ \\ ${ }^{1}$ Department of Dermatology, The Oxford Medical College, Hospital \& Research Centre, Bangalore, India \\ ${ }^{2}$ Department of Dermatology, Al Ameen Medical College and Hospital, Bijapur, Karnataka, India \\ Correspondence: Abhineetha Hosthota, E-mail: abhineethahosthota@yahoo.com \\ UDC 616.5-006-08:615.37
}

\begin{abstract}
Introduction. Warts are benign epithelial lesions that involve skin and mucosa. Successful management depends on the patient's immunity, site and type of wart. In spite of huge therapeutic armory available, no treatment has been found to be effective so far. Objective. To evaluate the effectiveness of autoimplantation in the management of multiple warts. Material and Methods. This is a hospital based prospective study of forty patients with multiple warts. A prospective, hospital-based study included forty cases of multiple warts for autoimplantation. Resolution of warts within three months was taken as complete clearance; the follow up of any recurrence lasted six months. Results. The majority of patients were males (69.7\%), belonging to 21-30 years age group (57.6\%). Complete resolution was observed in 25 patients, partial response was achieved in 5 patients and there was no response in 3 patients. The majority of patients did not have any complication or recurrence Conclusion. Autoimplantation is a simple, daycare, effective procedure. It provides resistance by inducing cell mediated immunity and also prevents recurrence to a great extent.
\end{abstract}

Key words: Warts; Transplantation, Autologous; Skin Transplantation; Recurrence; Treatment Outcome; Immunotherapy

\section{Introduction}

Viral warts are benign lesions involving epithelium of skin and mucus membrane caused by different strains of Human Papilloma Virus (HPV) (1). The clinical presentation of warts is variable and depends on HPV strain, site of infection and immunity of the patient. The most common clinical presentations are verruca vulgaris, verruca plana, palmoplantar warts and genital warts (condyloma acuminata). This is a common dermatologic complaint, which spreads by direct skinto-skin contact, fomites or autoinoculation (2).

The virus enters through abrasions on the skin surface and remains latent in the basal cell layer of the epidermis cell for 1 to 8 months (3). The process of virus replication produces proliferation of prickle cells which alters the character of the epidermis, resulting in the visible warty appearance of the verrucae. However, unlike many viruses, HPV infection spreads through shedding of infected epithelial cells from the surface of the skin. So, there is limited release of viral proteins to the circulating dendritic cells, causing inadequate antigen presentation to the immune system.
Furthermore, HPV proteins also encode specific functions to inhibit immune responses by inducing specific anti-inflammatory mechanisms by activating $T$ suppressor cells $(3,4)$. Due to the above pathomechanism warts are usually multiple and recalcitrant causing psychological distress to the patients and a therapeutic challenge for the dermatologists (5).

Previous literature has stated that warts resolve spontaneously in $40 \%$ of cases and others need medical or surgical intervention (5). Multiple treatment modalities are available for treating warts which destroy conspicuous infected tissue but there is no one such treatment which targets inconspicuous infected lesions to ward off further recurrence. Majority of treatments are direct, such as cryotherapy by liquid nitrogen, electrosurgery, lasers and photodynamic therapy. Numerous modes have been used to activate the immunological response such as oral levamisole, topical imiquimod and 5-FU, and intralesional immunotherapy with tuberculin antigen, MMR vaccine, BCG vaccine (6).

Rapid proliferation of wart in HIV-infected patients, solid organ transplant recipients and 
epidermodysplasia verruciformis is due to low T-lymphocyte cell count. Significant epidermal and dermal influx of CD4+ lymphocytes is seen in a spontaneously regressing wart. The above observations suggest that wart proliferation is controlled by cell-mediated immunity $(7,8)$. As the immune system seems to play an important role in the control of wart, there is a new inclination towards the use of immunotherapy. The current study was conducted to find autoimplantation as an effective immunotherapeutic approach in the treatment of multiple viral warts.

\section{Material and Methods}

This was a prospective, hospital-based study conducted at Dermatology Outpatient Department, The Oxford Medical College, Hospital \& Research Center (Bangalore, India), over a period of six months. The analysis included forty consecutive cases of warts in the patients (whose age ranged from 20 to 50 years) who did not have any other skin disease and who gave their consent to participate in this study. Patients with multiple (> five warts), verruca vulgaris, verruca plana and palmoplantar warts were enrolled. Pregnant, lactating mothers, immunocompromised individuals were excluded from the study. The patients were assessed monthly; resolution of all warts within 3 months was

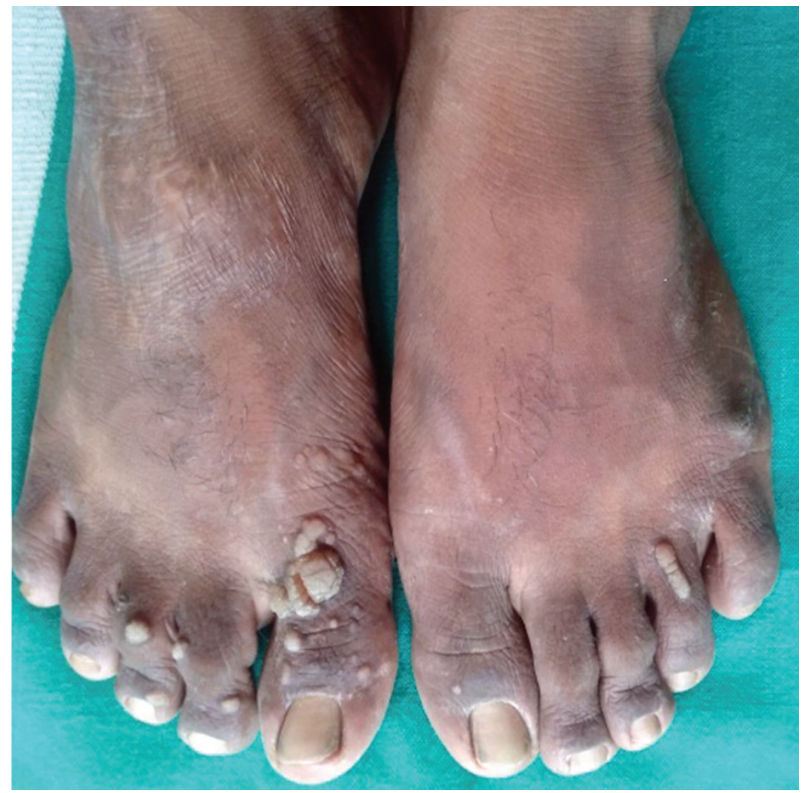

Figure 1. Before autoimplantation taken as complete clearance. The patients were followed up for six months after clearance of lesions for any recurrence. Institutional ethical clearance was granted.

\section{Autoimplantation Methodology}

The enrolled patients were prepared after testing for lignocaine $2 \%$ sensitivity. The wart of at least $5 \mathrm{~mm}$ size was cleansed with povidine iodine solution and excised under local anaesthesia (2\% lignocaine). The wound was then cauterized at borders and sealed with Povidine iodine ointment. The excised wart tissue was immersed in normal saline for 5 minutes, minced into tiny pieces. A small incision $(1 \mathrm{~cm})$ was made in the anterior aspect of mid thigh under local anaesthesia. A dermal pocket was created with an artery forceps and the minced wart tissue was placed and pushed under the skin, away from the incision site. The incision was then sutured using Prolene and dressed. Tablet Azithromycin $500 \mathrm{mg}$ was given for 5 days and the suture was removed on the 10th day. The patients were reviewed every four weeks for 3 months. Every follow up visit was aimed at observing the regression in size and number of warts every month, complete resolution of warts in 12 weeks, any recurrence of lesions during 6 months all in order to analyze the efficacy of autoimplantation.

\section{Results}

Out of 40 enrolled cases, 7 were lost for follow-up and 33 patients were available for procedure and evaluation (Flow chart). Majority of the subjects were males (69.7\%), mostly belonging to the age group of $21-30$ years $(57.6 \%)$. Mean duration of disease was 14.72 \pm 4.12 months and number of lesions was 17.6 \pm 5.6 on average. Majority of study subjects were illiterate from low socioeconomic strata with rural background (Table 1). All of them had multiple wart lesions (Figure 1), 20 had verruca vulgaris, 8 had verruca plana and 5 with palmoplantar warts (Pie Chart).

After 4 weeks of autoimplantation, 5 cases $(15.1 \%)$ achieved complete resolution of lesions at the earliest and partial improvement was observed in 11 patients (33.3\%). Complete resolution of warts within 12 weeks was observed in 25 cases (75.7\%) (Figure 2). However, 5 patients had partial response and 
Table 1. Sociodemographic profile of patients

\begin{tabular}{lccc} 
Variables & & $\mathrm{n}=33$ & $\%$ \\
& Mean & $21.10 \pm 4.35$ & 57.6 \\
Age (years) & $21-30$ & 19 & 24.2 \\
& $31-40$ & 08 & 18.2 \\
& $41-50$ & 06 & 00.0 \\
Gender & $>50$ & 00 & 69.7 \\
\hline \multirow{2}{*}{ Place } & Male & 23 & 30.3 \\
\hline \multirow{3}{*}{ Socioeconomic status } & Female & 10 & 84.8 \\
& Rural & 28 & 15.2 \\
\hline \multirow{2}{*}{ Education } & Urban & 05 & 48.5 \\
& Low & 16 & 39.4 \\
& Middle & 13 & 12.1 \\
\hline \multirow{2}{*}{ Occupation } & High & 04 & 63.6 \\
& Illiterate & 21 & 33.3 \\
\hline \multirow{2}{*}{ Family history } & Literate & 11 & 39.4 \\
& Factory & 13 & 51.5 \\
\hline
\end{tabular}

Table 2. Follow up Visit

\begin{tabular}{lcccccc} 
Clinical response & 4 weeks & $\%$ & 8 weeks & $\%$ & 12 weeks & $\%$ \\
\hline No response & 11 & 33.3 & 07 & 21.2 & 03 & 9.1 \\
Partial response & 17 & 51.5 & 19 & 57.6 & 05 & 15.1 \\
Complete response & 05 & 15.1 & 07 & 21.2 & 25 & 75.7 \\
\hline
\end{tabular}

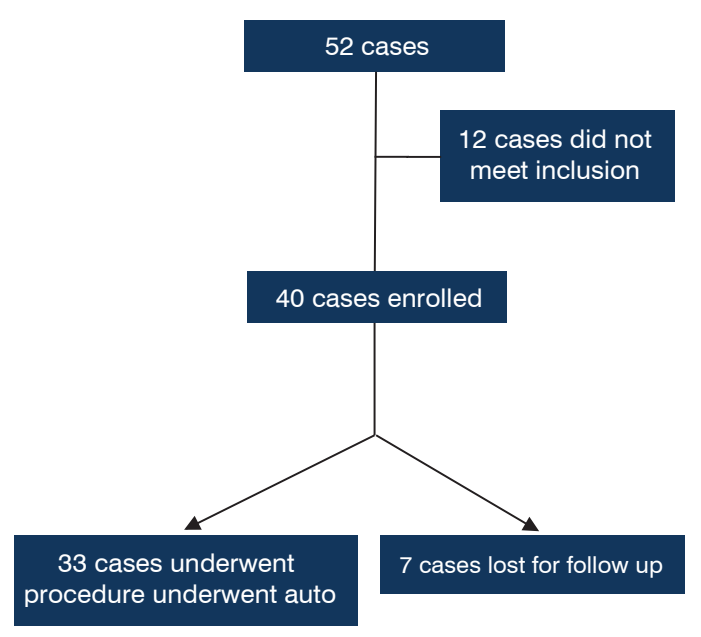

Flow chart
Type of wart

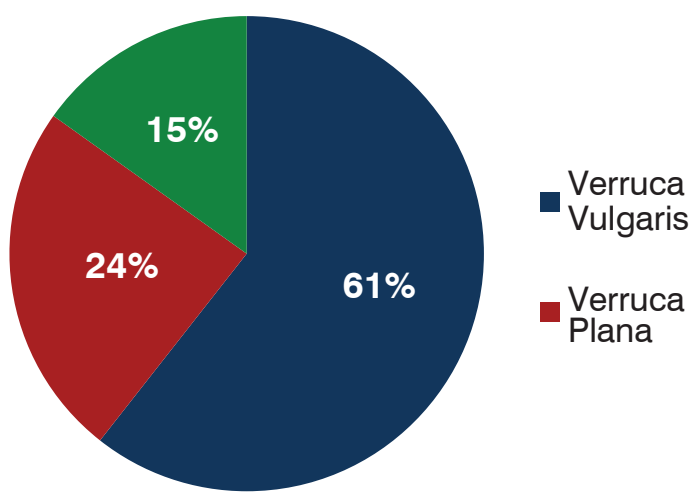

Pie Chart 


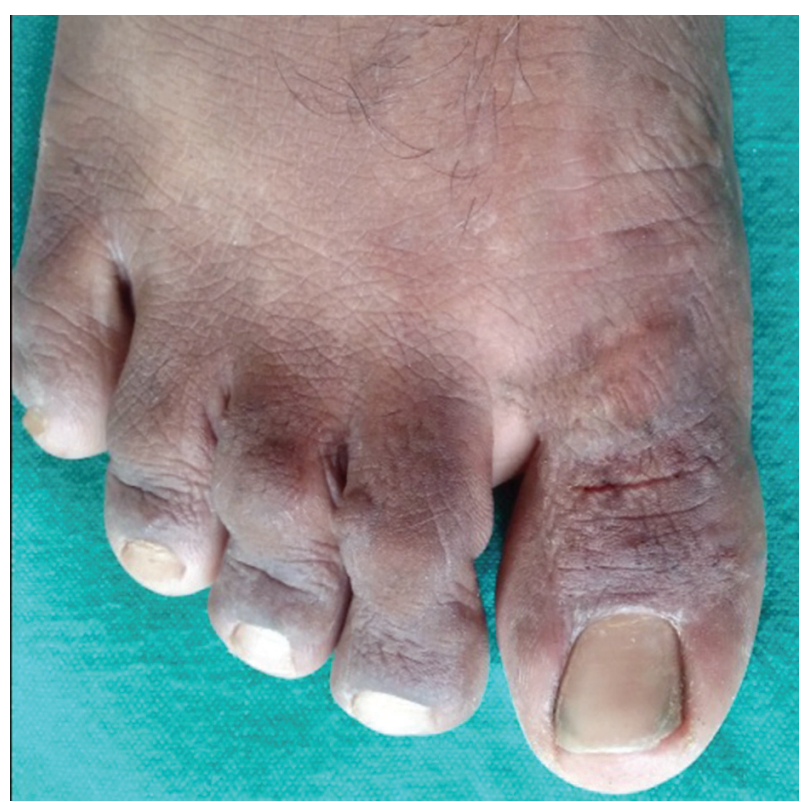

Figure 2. After autoimplantation

3 did not show any response at the end of 12 weeks (Table 2). During 6 months of observation we noticed 3 patients with recurrence of lesions at different sites.

Majority of patients did not have any complication. One patient noticed pus discharge at the site of implantation which was later treated with systemic antibiotics. Hyperpigmentation at the site of resolution of warts was noted in 3 patients.

\section{Discussion}

Management of warts is still a challenge and there is a dearth of ubiquitous consensus about therapeutic modalities in the literature. Warts have been exasperating for patients and clinicians for ages. They can greatly affect a patient's quality of life by causing embarrassment, fear of negative appraisal by others and frustration due to persistence or recurrence (9). One of the most challenging issues in the treatment of warts is the high recurrence rates (up to $30 \%$ or more), as the existing modalities of treatment do not eradicate the viral reservoir present in the adjacent tissues (10).

Common incidence of warts with its clinical significance, absence of specific antiviral therapy against HPV, variable efficacy of the available therapeutic modalities, high incidence of adverse effects and recurrence rates, particularly with the use of destructive approaches are the few factors which has paved the way for immunological therapeutics against HPV (10). Autoimplantation has a focused effect on immune response to HPV which has drawn interest but the progress has been slow over a decade.

In our study, males outnumbered females with mean age of presentation being $21.10 \pm 4.35$ years which is in concordance with previous studies $(11,12)$. Mean duration of illness was $14.72 \pm 4.12$ months that being congruent with Lal et al, whereas Das et al. observed that the majority (47\%) presented with warts within one year of appearance of lesions $(12,13)$. In the current study, the subjects had multiple warts; the majority of them had verruca vulgaris $(61 \%)$ followed by verruca plana and a few had plamoplantar warts. Similarly Swaroop et al. and Lal et al. observed verruca vulgaris, palmoplantar warts and periungual warts in their study $(11,12)$.

There is vast armamentarium for management of warts depending on the site, size and number of warts and side effects are the factors to determine the appropriate treatment which includes ablative or immunomodulatory modalities. Although $50 \%$ of warts resolve spontaneously within 1 year and $66 \%$ will resolve within 2 years, it can persist for years causing physical discomfort and psychological trauma (14). The treatment modalities available for recalcitrant warts are cryotherapy, lasers, intralesional bleomycin and 5\% imiquimod. Systemic retinoids, photodynamic therapy and topical sensitizers such as dinitriochlorobenzene (DNCB), squaric acid dibutylester (SADBE) and diphencyprone are reported to be effective for multiple lesions (15). In multiple warts on the palms and soles, destructive procedures are inappropriate and impractical (16). Studies have reported that intralesional immunotherapy has cleared distant warts without scarring, lower rate of recurrence and a high safety profile $(17,18)$. Combinations of treatment modalities have been tried with an average of $60.70 \%$ clearance in 3 months (5). Currently available destructive modalities may be painful, ineffective, expensive, associated with disfiguring scars and high recurrence rates (19).

Most of the treatments destroy affected tissues, either by cytotoxic or physically ablative mode of action. However, tissue damage alone may not be enough to produce the rel- 
evant cytokines to destroy latent virus in the adjacent cells. Thus the absence or reduction of a cellular response may explain many unsuccessful treatments even in immune-competent individuals $(4,20)$. The possibility of spreading to the close contacts and other sites demands a permanent cure. The ideal treatment for warts should avoid recurrence/persistence /reinfection, induce lifelong immunity to human papilloma viruses (5). This can be achieved by exposing viral antigens to immune mediators thus producing local as well as systemic immunity against HPV. Immunotherapy helps clinicians to target remote warts, multiple warts and warts at inaccessible sites. The best way to combat HPV infection would be by developing specific immune response targeted against early viral proteins. One way of achieving this would be by autoimplantation, which leads to better presentation of viral antigens.

We observed complete clearance of warts in $75.7 \%$ of cases in 12 weeks. Previous studies on autoimplantation have reported clearance rates from $62.5 \%$ to $74.1 \%(11,12,15,21)$. The lowest cure rates of $34.69 \%$ was reported by Gugle et al. (16). Partial clearance was noted in $15.1 \%$ of patients at the end of 12 weeks, a similar observation was made by Nischal et al. and Swaroop et al. $(11,21)$. In a study conducted by Gugle et al. 53.06\% the patients had partial clearance of warts which is much higher than our observation (16). In our study $9.1 \%$ of patients did not show any response to autoimplantation. This may be due to the presence of different type of warts in the same patients. However, we had the lowest failure rate compared to previous studies (11-30\%) (16). We did not find any significant association between duration, number/ site of warts at presentation and the outcome as reported by Lal et al. (12).

Autoinoculation leads to delayed hypersensitivity reaction to HPV antigens. There will be an alteration in cytokine profile, predominantly Th1 type, decreasing Th2 response. Th1 cytokines like TNF- $a$ and IL-1 down regulate transcription of HPV genes whereas INF-Y and IL-2 stimulate cytotoxic T cells and natural killer cells to eradicate HPV infected cells. Thus CMI enables the body to recognize antigens, stimulates production of memory $T$ cells against HPV and intensifies response mechanism to prevent recurrence (10).

Adverse effects noted in this study are purulent discharge and hyperpigmentation at the site of implantation was found in few patients. Erythematous nodule with discharge, keloids and hypopigmentation at the implantation site are the adverse events noted in previous literature $(11,12,15)$. Of the patients who had complete clearance, three came with recurrence within 6 months follow-up period. This may be due to the presence of periungual warts in them. As in this technique, it is more likely that immunity against the same serotype is elicited (16). Das et al. reported $3.33 \%$ of recurrence after one year of autoimplantation (13). This is in contrast to findings of previous investigators who did not report any recurrence during follow-up $(2,12,21)$.

Currently autoimplantation is not extensively practiced, which may be due to the lack of published research, and because clinicians prefer to utilize established treatment modalities such as cautery and cryotherapy. Autoimplantation has potential advantages such as treating distant, multiple warts in single sitting, difficult to treat areas like around eyes and periungual area. It is a simple, daycare procedure with promising efficacy and safety profile compared to other traditional therapies. The limitations of our study are short follow up period, and the fact that specific HPV type was not determined and immunity levels of cases before and after treatment were not assessed. There is scope for clinical groundwork to recommend standardized procedure with its efficacy and adverse effects.

\section{Conclusion}

Autoimplantation is an easy, day care, minimally invasive procedure which induces an immune response to aid in resolution of both treated and untreated warts. Every new trial on immune modification edges us closer to an effective and safe modality treatment of HPV. This is a promising modality of immunotherapy to be considered worthwhile to generate more randomized control trials data.

\section{Abbreviations \\ HPV-Human Papilloma Virus \\ HIV - human immunodeficiency virus \\ DNCB - dinitriochlorobenzene \\ SADBE - squaric acid dibutylester}




\section{References}

1. Plasencia JM. Cutaneous warts: diagnosis and treatment. Prim Care. 2000;27(2):423-34.

2. Das S, Chowdhury J, Patra S, Ghoshal L, Banerjee S. Auto-wart inoculation: an easy and effective treatment of multiple, recalcitrant and genital warts. Journal of Pakistan Association of Dermatology. 2016;26(3):229-34

3. Moghaddas N. Periungual verrucae diagnosis and treatment. Clin Podiatr Med Surg. 2004;21(4):651-61.

4. Longhurst $B$, Bristow I. The treatment of verrucae pedis using Falknor's needling method: a review of 46 cases. J Clin Med. 2013;2(2):13-21.

5. Sterling JC, Handfield-Jones S, Hudson PM. Guidelines for the management of cutaneous warts. $\mathrm{Br} \mathrm{J}$ Dermatol. 2001;144(1):4-11.

6. Gibbs S, Harvey I, Sterling J, Stark R. Local treatments for cutaneous warts: systematic review. BMJ. 2002; 325(7362):461.

7. Silverberg NB, Lim JK, Paller AS, Mancini AJ. Squaric acid immunotherapy for warts in children. J Am Acad Dermatol. 2000;42(5 Pt 1):803-8.

8. Gonçalves MA, Donadi EA. Immune cellular response to HPV: current concepts. Braz J Infect Dis. 2004;8(1):1-9.

9. Lipke MM. An armamentarium of wart treatments. Clin Med Res. 2006;4(4):273-93.

10. Nofal A, Salah E, Nofal E, Yosef A. Intralesional antigen immunotherapy for the treatment of warts: current concepts and future prospects. Am J Clin Dermatol. 2013;4 (4):253-60.

11. Swaroop MR, Sathyanarayana BD, Vasudevan P, Aneesa, Kumari P, Raghavendra J. Evaluation of efficacy and safety of modified technique of auto wart implantation in the treatment of multiple, recurrent and recalcitrant warts. Indian Journal of Clinical and Experimental Dermatology. 2016; 2(1):27-31.

12. Lal NR, Sil A, Gayen T, Bandyopadhyay D, Das NK. Safety and effectiveness of autoinoculation therapy in cutaneous warts: a double - blind, randomized, placebo - controlled study. Indian J Dermatol Venereol Leprol. 2014;80(6):515-20.

13. Das P, Sood A, Bhatnagar A, Verma R, Baveja S, Vashisht D. Clinical outcomes and recurrences after homologous autoimplantation therapy for warts: a prospective study. Journal of Marine Medical Society. 2017;19(2):103-7.

14. Kollipara R,Tyring SK. My Approach to the treatment of cutaneous (non-genital) warts [Internet]. 2015 [cited 2019 Dec 11]. Available from: www.practiceupdate.com/content/my-approach-to-the-treatment-of-cutaneous-nongenital-warts/24986.

15. Shivakumar V, Okade R, Rajkumar V. Autoimplantation therapy for multiple warts. Indian J Dermatol Venereol Leprol. 2009;75(6):593-5.

16. Gugle AS, Jadhav VM, Kote R, Deshmukh MD, Vankawala D. Study of homologous autoimplantation therapy for treatment of multiple warts in patients attending the dermatology out patient department. MVP Journal of Medical Sciences. 2015;2(2):110-7.

17. Lichon V, Khachemoune A. Plantar warts: a focus on treatment modalities. Dermatol Nurs. 2007;19(4):372-5.

18. Dasher DA, Burkhart CN, Morrell DS. Immunotherapy for childhood warts. Pediatr Ann. 2009;38(7):373-9.

19. Nofal A, Nofal E. Intralesional immunotherapy of common warts: successful treatment with mumps, measles and rubella vaccine. J Eur Acad Dermatol Venereol. 2010; 24(10):1166-70.

20. Bristow IR, Stiles CJ. The treatment of stubborn plantar warts using topical $5 \%$ imiquimod cream. Podiatry Review. 2012;69(1):6-13.

21. Nischal KC, Sowmya CS, Swaroop MR, Agrawal DP, Basavaraj HB, Sathyanarayana BD. A novel modification of the autoimplantation therapy for the treatment of multiple, recurrent and palmoplantar warts. J Cutan Aesthet Surg. 2012;5(1):26-9.

\section{Autoimplantacija - imunološki tretman za multiple verrucae vulgares}

\section{Sažetak}

Uvod. Bradavice ili veruke su benigne epitelne lezije koje zahvataju kožu i sluznicu. Uspešno lečenje zavisi od imunskog odgovora pacijenta, lokalizacije i tipa bradavica. Uprkos mnogim terapijskim metodama, nijedan tretman do danas nije u potpunosti efikasan u sprečavanju recidiva. Cilj. Proceniti efikasnost autoimplantacije u lečenju multiplih veruka. Materijal i metode. Prospektivna, bolnička studija obuhvatila je četrdeset pacijenata sa multiplim bradavicama kojima je urađena autoimplantacija. Rezolucija veruka u toku od tri meseca smatrana je kao kompletan odgovor na terapiju. Pa- cijenti su praćeni tokom šest meseci u cilju registrovanja recidiva. Rezultati. Većina pacijenata bili su muškarci $(69,7 \%)$, koji su pripadali starosnoj grupi $21-30$ godina (57,6\%). Potpuna rezolucija uočena je kod 25 pacijenata, delimičan terapijski odgovor kod pet, odsustvo efekta kod tri pacijenta, a sedam je izgubljeno iz praćenja. Većina nije imala komplikacije ili recidive. Zaključak. Autoimplantacija je jednostavan, efikasan postupak koji se sprovodi ambulantno. Obezbeđuje otpornost prema HPV virusima indukujući imunski odgovor posredovan ćelijama i u velikoj meri sprečava recidiv.

Ključne reči: Bradavice; Autologna transplantacija; Transplantacija kože; Recidiv; Ishod terapije; Imunoterapija

Received 21.02.2020.

Accepted 6.05.2020. 